\title{
Michał Pospiszyl
}

\section{Teologia peryferii}

Choć niemal cała współczesna lewica spogląda w kierunku Ameryki Łacińskiej z nadzieją na narodziny prawdziwie radykalnego ruchu społecznego, to polska recepcja teologii wyzwolenia - kluczowej dla zrozumienia walk i oporów w tym regionie - praktycznie nie istnieje. W pewnym sensie trudno się dziwić. Z jednej strony polska teologia musi znieść piętno Karola Wojtyły, który jako papież w zasadzie unicestwił ją jako dziedzinę w jakimkolwiek znaczeniu twórczą i krytyczną, z drugiej - rodzima lewica, od której oczekiwać by można przychylniejszego spojrzenia na teologię wyzwolenia, działając w środowisku dominacji dyskursu narodowo-katolickiego, dostaje spazmów już na sam dźwięk tego słowa.

W tym sensie nowa książka meksykańskiego marksisty Luisa Martineza Andrade (zbiór świetnie napisanych odrębnych esejów, ułożonych jednak w bardzo przemyślany sposób, pojawiających się w Polsce pod tytułem Ameryka Eacińska: religia bez odkupienia. Sprzeczności spoteczne i sny na jawie) może przyczynić się do rozbicia tego osobliwego sojuszu, jaki polska lewica zawiera dziś z polskim Kościołem, jednogłośnie (choć z różnych powodów) odrzucając dziedzictwo lewicowej teologii.

Teza Martineza Andrade jest prosta i znajduje zresztą wśród marksistowskich teoretyków wielu protoplastów (od Marksa aż po Deborda): religia jest zjawiskiem w najwyższym stopniu ambiwalentnym, a jej oświeceniowa, mocno sekularna krytyka, budzi wątpliwości nie tylko dlatego, że zwykle przeprowadzają ją biali wykształceni mężczyźni z klasy 
$Z$ jednej strony zatem Martinez Andrade akcentuje na każdym kroku (zresztą całkiem zasadnie) polityczną szkodliwość French Theory, z drugiej ciaggle przypomina

o konieczności zdekonstruowania aliansu, w jakim tkwią od samego początku nowoczesność i kolonializm średniej, mogący z mniej lub bardziej artykułowaną pogardą odnosić się do wszystkich tych, którym religia przynosi ukojenie (bo sami owego ukojeniu nie potrzebuja). Budzi je także dlatego, że - jak pokazuje historia walk społecznych (paradoksalnie, szczególnie w regionach, które zostały zmuszone do przyjęcia chrześcijaństwa pod kolonialnym terrorem) - religia, o ile wyzwolić ją z instytucyjnego pręgierza, staje się jednym z najmocniejszych narzędzi walki z biedą, z podziałami klasowymi, genderowymi czy rasowymi. Chodzi zatem (i jest to oś argumentacji książki Martineza Andrade) o to, żeby czytać religię jako rodzaj nie tylko ideologicznego kamuflażu, którym klasy panujące zakrywają i pacyfikują wszelkie niezadowolenie (choć jego ujawnienie jest rzecz jasna absolutnie zasadnicze), ale spróbować wykrzesać z religii utopijną iskrę, dającą nadzieję na powodzenie rewolucyjnej walki.

Oczywiście nie znaczy to wcale, że kolonialny opór nie mógłby się dokonywać bez chrześcijaństwa (w wielu wypadkach wcale go nie potrzebował), jednak podobnie jak w wypadku oświeceniowego ratio, którego narodziny Martinez Andrade za Enrique Dusselem umieszcza w roku 1492 (ego conquiro jako poprzedzające o sto lat ego cogito), historia walk społecznych na peryferiach wskazuje raczej na konieczność użycia i wykorzystania przeciwko opresorom narzędzi, którymi cały czas niszczą oni swoje kolonie i podporządkowują ich mieszkańców.

Dlatego też jednym z nieustannie podkreślanych przez meksykańskiego teoretyka momentów jest konieczność przyjęcia i modyfikacji tradycji oświecenia, tak niebezpiecznie atakowanej od kilku dekad z poststrukturalistycznych (a tym samym, jak twierdzi Martinez Andrade, anty-politycznych) pozycji. Nieufność meksykańskiego socjologa wobec poststrukturalizmu jest skądinąd chyba nieco przesadzona. W zasadzie teoretyczny efekt tej krytyki postmodernizmu przypomina pojęcie alter-nowoczesności, którym posługują się m.in. Hardt i Negri, a pod którym umieszczają przecież także silny moment anty-nowoczesny, niesiony tak przez anty-kolonialny opór, jak i właśnie postmodernistyczną krytykę oświecenia ${ }^{1}$. Z jednej strony zatem Martinez Andrade akcentuje na każdym kroku (zresztą całkiem zasadnie) polityczną szkodliwość French Theory, z drugiej - ciągle przypomina o konieczności zdekonstruowania aliansu, w jakim tkwią od samego początku nowoczesność i kolonializm.

Ambiwalencję, którą Martinez Andrade żywi nie tylko wobec religii, ale także wobec nowoczesności, dobrze widać w tym, jak pisze on o kluczowej dla marksizmu kategorii Całości:

1 M. Hardt, A. Negri, Commonwealth, Cambridge MA 2009, s. 101-119. 
nadal ważna jest "całość« jako kategoria krytyczna, ponieważ, jak mówi Žižek, kategoria ta nie odnosi się do harmonii ukrytej w Całości, lecz obejmuje w łonie systemu jego wszystkie symptomy, a tym samym jego antagonizm i niespójności, jako części składowe. Dlatego postulaty społeczne czy kulturowe nie powinny być oderwane od kwestii ekonomicznej - jej pominięcie może zachęcać do reifikacji systemu ${ }^{2}$.

Chodzi zatem o taki rodzaj teorii, która będzie myśleć o całości raczej jak o całokształcie [ensamble] stosunków społeczno-ekonomicznych (nigdy niezesencjonalizowanych $\mathrm{w}$ takiej czy innej finalnej postaci), niż o całości w sensie niemieckiego Ganze $e^{3}$. Oznacza to rezygnację z twardooświeceniowej intuicji na rzecz kłącza czy sieci relacji, które kształtują stosunki społeczne.

Tym, co jednak najbardziej interesujące w pojęciu nowoczesności, jakie próbuje, przy wsparciu kilku autorów, forsować Martinez Andrade, jest ujawnienie i podkreślenie kolonialnego uwikłania, w jakie wpleciony jest logos oświecenia (a o którym zapominają albo chcą zapomnieć wszyscy apologeci europocentrycznej wizji oświecenia od Kanta aż po Habermasa). Chodzi tu zatem, po pierwsze, o ujawnienie mechanizmu konstruowania nowoczesności w oparciu o zanegowanie inności, którą jeszcze w analizach Foucaulta stanowiło szaleństwo ${ }^{4}$, a którą - jak przekonuje Martinez Andrade - pierwotnie był świat indiański. Po drugie, chodzi także o zrelatywizowanie europejskiej potęgi jako przygodnej i powstałej w efekcie kilku sprzyjających jej zbiegów okoliczności, które umożliwity kolonialną ofensywę Zachodu i powstrzymały prawdopodobnie lepiej do tego przygotowane Chiny ${ }^{5}$. Po trzecie w końcu o wskazanie na kolonializm nie tylko jako wytwór kapitalizmu i oświecenia, ale jako na jego mechanizm napędowy, działający na zasadzie

2 L. Martinez Andrade, Ameryka Eacińska: religia bez odkupienia. Sprzeczności spoteczne i sny na jawie, tłum. Z. M. Kowalewski, Warszawa 2012, s. 63.

3 E. Balibar, Filozofia Marksa, tłum. Z.M. Kowalewski, A. Ostolski, A. Staroń, Warszawa 2007, s. 45.

4 M. Foucault, Porzadek dyskursu, tłum. M. Kozłowski, Gdańsk 2002.

5 Jak twierdzą Gavin Menzies i Enrique Dussel, Chińczycy opłynęli kulę ziemską już na początku piętnastego wieku, ale pod wpływem decyzji cesarza Hongxi (z dynastii Ming) z 1424 roku zrezygnowali z zamorskich i kosztowych podbojów (co miało być powodowane troską cesarza o głodujących wówczas poddanych). Taka decyzja przyczyniła się jednak do jeszcze głębszej klęski żywnościowo-ekologicznej (a ta z kolei - do zmiany polityki gospodarczej, powstrzymującej narodziny kapitalizmu w Państwie Środka), która dotknęła Chiny z powodu przeludnienia i braku kolonii, które to kolonie (jak pokazuje z kolei historia Wielkiej Brytanii) zdolne były pochłonąć każdą nadwyżkę demograficzną. 
sprzężenia zwrotnego, to znaczy wzmacniany przez i wzmacniający rozum, postęp czy rozwój.

Dekonstrukcja europocentrycznej wizji oświecenia powinna się zatem dokonać z „krytyczno-analektycznego i wyzwoleńczego punktu widzenia" ${ }^{\prime}$, tym samym koncentrując się na cielesności, stanowiącej, jak twierdzi meksykański socjolog, nośnik historii kulturowych, szczególnie ważnych z peryferyjnej perspektywy. Włączenie kapitału somatycznego do teorii postkolonialnej rozwijanej przez Martineza Andrade zdecydowanie wzbogaca i rozjaśnia prowadzone w tym paradygmacie analizy. Co ciekawe, dokonuje się tu ono za pomocą m.in. myśli Emanuela Lévinasa (filozofa w Polsce szczególnie hołubionego), dla którego twarz Innego jest miejscem rozbicia własnej, także cielesnej, tożsamości. Filozofia Lévinasa, co z polskiej perspektywy może wydawać się kuriozalne, miała zresztą być jedną z podstawowych inspiracji do przejścia Dussela (postaci kluczowej dla całej książki) na pozycje marksistowskie. Problem, który wynika z tego typu koncepcji (a który dostrzega także argentyński myśliciel), to jej ostateczny europocentryzm, zgodnie z którym Inny może być wyłącznie semitą - nie zaś Indianką, Afrykanką czy Azjatką.

Płytkość Lévinasa w tej kwestii pokazuje zresztą dość dobitnie Spivak, krytykująca etyczny paradygmat (zastąpiona rzecz projektu erotyczno-translacyjnego), przyświecający tej filozofii, związany - jak twierdzi zawsze w ten czy inny sposób z kwestią reprezentacji ${ }^{7}$. Etyczny podmiot zatem, chcąc działać w imię „sieroty, wdowy czy cudzoziemki”, musi ustanawiać hierarchie całkowicie sprzeczną z niezliczonymi deklaracjami Lévinasa, dla którego asymetria relacji ja-Inny wydaje się na pierwszy rzut oka skrajnie preferować Innego. Tym samym „ja” pełni w tej filozofii ostatecznie dokładnie tę samą paternalistyczną funkcję (doskonałej świadomości tego, co będzie dla Innego dobre), którą miało zabić rozbijające tożsamość doświadczenie twarzy.

Wysiłek Martineza Andrade (czy Dussela) koncentruje się jednak nie tyle na kwestii krytyki filozofii reprezentacji, ale raczej na próbie użycia europejskiej filozofii ciała do opisu kapitału cielesnego jako jednego (obok kapitału symbolicznego) z gwarantów uzyskanego na peryferiach prestiżu, który zapewnia ,wizerunek pasujący do hegemonicznego stereotypu kolonialnego" ". Co jednak uderzające w całej książce, to de facto brak perspektywy feministycznej. W zdominowanej raczej przez

6 L. Martinez Andrade, Ameryka Eacińska..., s. 72.

7 G. Spivak, Polityka przektadu, tłum. D. Kołodziejczyk, [w:] Wspótczesne teorie przektadu, red. P. Bukowski, M. Heydel, Kraków 2009, s. 420-421.

8 L. Martinez Andrade, Ameryka Eacińska..., s. 97. 
mężczyzn teologii wyzwolenia jest ona - wprawdzie słabo - reprezentowana; tym silniej zaznacza się więc jej pominięcie przy analizach ciała, zapoczątkowanych przecież tak przez feministyczne fenomenolożki, jak i tuzy współczesnej filozofii w rodzaju Butler czy Spivak. Brak ten z pewnością należy do najsłabszych momentów całej książki.

Jak w związku z kwestią reprezentacji podkreśla meksykański teoretyk, walka z hegemonicznym paradygmatem musi doprowadzić do całkowitego z nim zerwania, które nie może „polegać na „uniżeniu” się [hegemona - MP] [kenosis] i łaskawym "udzieleniu głosu " wyklętemu ludowi ziemi, jak to wyniośle proponują nam niektórzy, lecz na symetrycznej komunikacji miedzy ludami"9 . Dopiero taka perspektywa, zrywająca także z Lévinasowskim paternalizmem, umożliwi realne wyzwolenie, o które toczy się tu walka.

Starcie to rozgrywa się nie tylko na poziomie egalitarnych i oderwanych od teorii roszczeń, ale zawsze jest też sporem o nowoczesność, mesjanizm czy religię oraz funkcję, jaką te pojęcia pełnią w analizie społecznej. Jak już pokazałem, stosunek autora do religii jest nacechowany (przejętą bezpośrednio od Blocha, a de facto od samego Marksa) ambiwalencją, w perspektywie której religia odgrywa rolę nie tylko ideologiczną, ale także utopijną. Obie role wyraźnie oddziela Bloch pod pojęciami utopii abstrakcyjnej (którą obiecuje ideologia kapitalistyczna) i utopii konkretnej (o którą walczy marksizm). Takie ujęcie, w którym kapitalizm rozumiany jest jako nosiciel mesjańskiej obietnicy, ma tylko częściowe uzasadnienie. Nie ulega wątpliwości pewien emancypacyjny potencjał, który przynosi kapitalizm, a który tak zachwycał Marksa jeszcze w Manifeście komunistycznym. Jeśli zatrzymać się na tym etapie, to kapitalizm realizuje także pewne cechy utopii konkretnej: znosi przecież świętości starego feudalnego świata, zastępując go nagim stosunkiem ekonomicznym, ale także obiecuje, że każdy i każda, jeśli tylko zdobędzie się na odpowiedni wysiłek, może osiągnąć sukces (blokowany do tej pory przez uświęcony porządek feudalny).

Jednak jeśli rozumieć mesjanizm jako tradycję walki z mitem (a taka perspektywa zaznacza się już od starożytnego judaizmu aż do oświeceniowego exodusu ze słynnego Kantowskiego eseju Odpowiedź na pytanie: czym jest oświecenie?), to mesjanizm kapitalistyczny jest mesjanizmem symulowanym. Markuje jedynie emancypacyjny krok, wyzwalający z feudalnych fetyszy, by w tym samym momencie ustanowić nowy porządek nowych świętości, opanowanych tak przez boską siłę (zdolnego

9 Tamże, s. 101.

\section{Mesjanizm}

kapitalistyczny jest mesjanizmem

symulowanym.

Markuje jedynie

emancypacyjny krok,

wyzwalający

z feudalnych fetyszy,

by w tym samym

momencie ustanowić

nowy porządek nowych

świętości,

opanowanych tak przez

boską siłę (zdolnego

przekształcić świat

w dowolny sposób)

pieniądza 
przekształcić świat w dowolny sposób) pieniądza ${ }^{10}$, jak przez mityczno-fetyszystyczną moc handlu i towaru ${ }^{11}$.

Ta mityczna w istocie (a nie - jak chce ją określać za Blochem Martinez Andrade - mesjańska) siła doskonale wpisuje się w Blochowski podział na sen nocny i dzienny. Pierwszy nie posiada cezury i świat zewnętrzny jest w nim zablokowany (co uniemożliwia wszelką praxis), drugi „może skanalizować całą siłę zawartą w podmiocie na działanie zmierzające do przeobrażenia świata i w tym znaczeniu zawsze maluje lepszy świat" ${ }^{2}$. Sen nocny zatem staje się nośnikiem (mitycznej) ideologii kapitalistycznej, dzienny zaś ma przynosić (mesjańska) nadzieję na świat wyzwolony z klasowych podziałów.

Z tej perspektywy oczywiście czujny i zawsze czuwający podmiot lansowany na Zachodzie od Kartezjusza po Husserla, wiążący trzeźwość z zaufaniem wynikom matematycznego przyrodoznawstwa, staje się niczym więcej, jak warunkiem możliwości tego, by bezrozumny lud spał spokojnie zanurzony w biernym śnie nocnym, pod bacznym okiem tych, którym udało się przekonać resztę społeczeństwa, że dostąpili możliwości oglądania rzeczy samych. Tak skonstruowana dystynkcja domaga się nie tylko krytyki metodologicznej (zgodnie ze zdecydowaną większością opisów nauki, trudno jest mówić o tym, by jakiekolwiek odkrycie było ostateczne i prawdziwe, a tym samym, by sankcjonowało poznawczy elitaryzm), ale także społecznej walki o egalitaryzm, która - tak w wypadku Blocha, jak i jego teologicznych kontynuatorów - powinna być także walką o przyrodę.

Sojusz teologii z ekologią może wydawać się jednak podejrzany. Biblia przecież obfituje w opisy, potwierdzające wyróżnioną pozycję człowieka w przyrodzie, a nawet w takie, które sankcjonują jego dominacje i ekspansję. Za ekologiczną katastrofę, jak twierdzi Martinez Andrade, odpowiada nie tyle chrześcijaństwo, ile stosunki ekonomiczne wygenerowane w kapitalizmie, na które świadomość religijna miała mieć znikomy wpływ. Niezależnie od kontrowersyjności tej tezy (wydaje się, że chrześcijaństwo stanowi po dziś dzień doskonałe ideologiczne narzędzie do uzasadniania gigantycznej eksploatacji środowiska), to przecież nie brakuje w Biblii przykładów wspierających dokładnie odwrotną intuicję ${ }^{13}$. Najbardziej

10 K. Marks, Rękopisy ekonomiczno-filozoficzne z 1844 r., tłum. K. Jażdżewski, [w:] K. Marks, F. Engels, Dzieta, t. 1, Warszawa 1960, s. 612.

11 K. Marks, Kapitat, t. 1, [w:] K. Marks, F. Engels, Dzieta, t. 23, Warszawa 1968.

12 L. Martinez Andrade, Ameryka Eacińska..., s. 113.

13 Martinez Andrade raczej ogranicza się do sprawozdania z tego, jak ta kwestia jest godzona od Blocha po Dussela, niż szuka własnego argumentu w oparciu o źródła. 
błyskotliwie wypadają te, którymi posługuje się Bruno Latour w eseju o teologii ekologicznej, gdzie zachęca do tego, by uwzględnić tradycję mesjańską przy przeformułowywaniu projektu modernizacyjnego tak, by przeciąć ograniczającą nas alternatywę „,modernizacja czy ekologizacja” ${ }^{14}$.

Szczególnie interesująca w książce Martineza Andrade jest (może nieco podskórnie) zaakcentowana peryferyjność teologii wyzwolenia ${ }^{15}$, która każe zadać pytanie o uniwersalność przedstawianych analiz. Czy teologia wyzwolenia ma ten sam wywrotowy potencjał w krajach centrum i (pół) peryferii, podobnych do Polski? Czy jej emancypacyjna siła nie ogranicza się do wyklętego ludu ziemi, którego wyzwolenie będzie (zgodnie ze starym Marksowskim mechanizmem) wyzwoleniem całego globu? Tym samym - uniemożliwiający w strukturalny sposób rozwój radykalnej myśli teologicznej na przykład w Polsce (wówczas przywołana na początku, reakcyjna postać Wojtyły byłaby jedynie symptomem tak czy inaczej tłumiącej wszelki emancypacyjnych ruch struktury). Problem ten jest zresztą dużo szerszy, w pewnym sensie rozbija się o niego także ostatnia książka Jana Sowy ${ }^{16}$, której autor próbuje czytać historię Polski w postkolonialnym kluczu, stwierdzając w ten sposób, że ewentualne wyzwolenie Polski jako kraju (pół)peryferyjnego, dzięki geograficznej i kulturowej bliskość krajów centrum, może być dużo trudniejsze niż wyzwolenie niektórych jeszcze do niedawna całkowicie peryferyjnych państw, takich jak Singapur, Tajwan czy Korea Południowa. Jeśli uznać diagnozę Sowy za słuszną, to także trudno oczekiwać po rodzimej teologii, by zdolna była wyrwać się z opresji watykańskiego centrum. A jak pokazuje historia polskiego Kościoła, należy raczej oczekiwać nadgorliwej próby powtórzenia konserwatywnej teologii Watykanu, niż jej jakiejś zasadniczej modyfikacji1"

14 B. Latour, Czy nie-ludzie zostana zbawieni?: argument ekoteologiczny, tłum. M. Bokiniec, [w:] Ekologia: przewodnik „Krytyki Politycznej”, Warszawa 2009, s. 26.

15 Dwaj główni bohaterowie książki Martineza Andrade: Dussel i Boff, przeszli wręcz modelową dla postkolonialnych teoretyków drogę kariery akademickiej. Pochodzący z peryferii (pierwszy z Argentyny, drugi z Brazylii), obaj kształcili się na Zachodzie. Boff napisał nawet doktorat u Ratzingera, który później zabiegał zresztą usilnie o jego wydanie (ten sam Ratzinger w latach osiemdziesiątych będzie wnosił o ukaranie niepokornego teologa). Dussel z kolei odbył studia w Instytucie Katolickim w Paryżu.

16 J. Sowa, Fantomowe ciato króla: peryferyjne zmagania z nowoczesna forma, Kraków 2012.

17 Mechanizm ten został zresztą doskonale opisany w: H. Bhabha, Mimikra i ludzie: o dwuznaczności dyskursu kolonialnego, tłum. T. Dobrogoszcz, „Literatura na Świecie" 2008, nr 1-2. 
Michał Pospiszyl - filozof i kulturoznawca. Zajmuje się marksizmem, filozofią kultury i wątkami teologicznymi w myśli politycznej. Aktualnie pisze prace o związkach włoskiego operaismo z estetyką relacyjną w Instytucie Kultury UJ.

Dane adresowe:

Wydział Filozoficzny UPJPII

ul. Kanonicza pok. 203

31-002 Kraków

e-mail: pospiszyl.michal@gmail.com

Cytowanie:

M. Pospiszyl, Teologia peryferii, „Praktyka Teoretyczna” nr 5/2012, http:// www.praktykateoretyczna.pl/PT_nr5_2012_Logika_sensu/21.Pospiszyl. pdf (dostęp dzień miesiąc rok)

Author: Michał Pospiszyl

Title: Theology of the periphery 